\title{
FAMILY NEEDS OF INCURABLE ILL CHILDREN IN THE CONTEXT OF SPECIAL EDUCATION

\author{
Kristína Nagyová ${ }^{1}$, Terézia Harčaríková ${ }^{2}$
}

\begin{abstract}
Incurable disease of children is one of the most difficult periods in the life of a family. The family must adapt to the new challenges that bring the illness and everything adapts to the needs of the child. However, we often don't realize and even don't know that the family needs must also be fulfilled. The paper presents partial results of the research aimed at identifying the needs of the family with an incurable ill child in a special pedagogical context. For the collection of research data a semistructured interview with assistants working in the area of child palliative care was conducted. The obtained data were processed by qualitative analysis. The results point to the necessity of a transdisciplinary approach to children with incurable illness and their families - psychologist, social worker, clergymen, and special educator.
\end{abstract}

UDC Classification: 376, DOI: 10.12955/cbup.v7.1412

Keywords: Incurable illness, palliative care, family, needs.

\section{Introduction}

The need is a state of lack or surplus, which deviate humans from their optimal state. Maslow (1943) argues that needs are organized among themselves according to mutual dominance. For humans, the most important needs, which are primarily in the hierarchy, are the biological needs, with that of a person achieving physical homeostasis. Other needs include the need for security, which is just as important as biological needs, and is particularly noticeable in small children who also respond to the smallest threats, such as parents' quarrels. As the third in the hierarchy, the author mentions the need for love. It is actually the social needs of an individual. To this the author does not include sexual needs, which, in his view, is exclusively a biological need. Another need is the need for respect. The last and greatest need is the need for self-actualization. For a person, this need means becoming the one he wants to be. Maslow was criticized by some authors for the fact that the needs he describes as universal were only found in healthy individuals and individuals who are somewhat handicapped, may have different needs. On the other hand, the World Health Organization (Marmot et. al., 2011) provides us with a classification of needs that occur in sick people. The WHO mentions the basic (primary) needs: biological needs with priority to be met. Other needs include the World Health Organization's psychological, social, spiritual, and environmental needs.

\section{Biological needs of the family with incurable ill children}

Illness of a family member has a significant impact on changing the lifestyle of the family. Nevertheless, there are not many references in the literature that the family with an ill child would have less saturated biological needs than ordinary families. The most commonly mentioned biological need is for parents to have a rest. Child care with an illness is very tiring for parents, not just to the parent who is at home (primary mother), but also to the parent who provides the family income, and after work coming home has to take care of the family and help care for the sick child and the household.

If we were to maintain the exact definition of biological needs according to Maslow (1943) and consider sexual need as purely biological, Lavee and May-Dan (2003) state that this area is deficient in parents who care for a sick child, this need is more intensely perceived by men.

\section{Psychological needs}

Among the psychological needs that are stated by Maslow (1943) we may include the need for safety and certainty and the need for self-actualization. Matejček (2014) among other psychological needs includes: Stimulation need - there is a need for a reasonable amount of stimulus from the outside world. In the case of families with an incurable ill child, these stimulants cannot be absent, especially if the family has been taking care of the child for a long time and their contact with the outside environment is limited. The need for a meaningful world - it is about the need of person to have a structure in life. At the time of the child's illness, however, the structure of life and, in particular, the familiar structure of the family breaks and brings it other problems and difficulties. The need for positive identity and selfneed - this need concerns the acceptance of its social value. For families with an ill child, this need may be limited to a certain extent, especially for mothers who spend the entire time on demanding child care

\footnotetext{
${ }^{1}$ Faculty of Education, Comenius University in Bratislava, Slovakia, nagyova.kristina25@gmail.com

${ }^{2}$ Faculty of Education, Comenius University in Bratislava, Slovakia, harcarikova@ fedu.uniba.sk
} 
or are hospitalized with them. The need for an open future - in this need, we are talking about hope and life perspectives. In the case of families with an incurable ill child, this need is imperative, although it may not be for the members or siblings themselves; the family loses the perspective of the future because they know that the life of one member is coming to an end, which can cause feelings of despair and hopelessness in the family. The need for safety and certainty - we have included a number of ways mentioned by authors in this category because this need appears to be most inadequate in parents with an incurable ill child. As has been shown, the way parents get a sense of security to reduce their stress, anxiety or fear is fulfilling the need for information, especially about the health of the child. Several authors describe a high prevalence of information in parents. Hallström and Elander (2007) found that this need was even greater than the need for emotional support. Need for parents to be informed families, especially in the short-term after the communication of a diagnosis, and the first information they receive from the doctor begin to search for disease information. The most accessible resource for the family is the internet, where they can read through various articles and forums about how the illness will proceed or if there are experiences of families with the same illness. Parents can find this information at the illness denial stage when they try to find situations when people have been diagnosed with the illness. Several authors describe that the need for information is one of the most important needs for the family and especially for parents (Brown and Warr, 2007; Ondri and Cínová, 2013; Yoshida, 2014). Hallström and Elander (2007) report that parents need for information is not related only to the diagnosis, but also about the prognosis, the possible health complications, the risk of the disease and the tests the child has to undergo.

\section{Psychosocial needs}

Kohoutek (2009) writes that psychosocial or social-psychological needs are the needs, which we gain. In this case, it is a combination of psychological and social needs. In particular, these needs relate to social security and social support, which gives the individual a sense of social security, but also relates to social contact and emotional demands. One of the psychosocial needs of families with an incurable ill child is the need for support, or we can also call it the need for psychosocial support. At the time of communication of the diagnosis, the family should be given the possibility of support, which also becomes one of their needs, and changes during the progression of the child's illness. Family support should be a multidisciplinary issue and should respond to the current needs of the family. The family needs supervision and counseling, needs to make sure that they is not alone in this situation, and that the experts are ready to help them at any time (Hallströmm and Elander, 2007). Support for individual members should start primarily in the family. Family members expect from other members support, especially emotional, but Machado et al. (2010) write, that they are not always able to provide this support because they are sometimes the ones who need to support themselves. At that time, it is important that this support is given to them by close persons and a wider family. Hallströmm and Elander (2007) say that it is sometimes very helpful for parents when grandparents, for example, help guard the child. They emphasize the importance of community support where parents can share their feelings and experiences. This is primarily a community of friends, groups of parents with a similar problems and, last but not least, church communities. In institutional care and family support, professionals should focus on improving the psychological, emotional and spiritual comfort of the family. The multidisciplinary care should include the work of social workers, intellectuals, psychologists, and also the importance of expressive therapies such as music therapy, art therapy and play therapy.

Another category of psychosocial needs is the need for love and emotional fulfillment. Parents do not have time on each other, siblings often remain less noticeable and everything in the family is adapted to the ill child. This is where the need arises for affectionate relationships and emotional fulfillment. Brown and Warr (2007) write that families need to find a balance between change and stability, and their relationships must adapt to the development of the social and emotional life of family members. As we have suggested above, communication is the basis of meeting this need. Lane and Mason (2014) emphasize that communication should be open and honest among parents. Parent-child communication should also be open, taking into account the child's developmental stage.

\section{Social needs}

We may include financial and material need for social needs that occur in families with an incurable ill child. Taking care of the terminally ill child brings with it financial and material problems as well. In most families, one of the parents remains with the ill child and the family then lives on only one income. 
Eiser and Upton (2006) found that a family with a child with cancer has the highest family expenses for the first 6 months after diagnosis. When a child stays in home care, most of the money is spent on the special equipment the child needs. This may include, for example, a removable bed, a carriage or a wheelchair. Also in some cases the family must provide pumps, alarms, monitors, and other medical devices. Other expenses the family needs to invest in are housing arrangements for the sick child who often needs barrier-free access. Sometimes an ill child cannot normally eat, so the family must provide a special diet for the baby who has to eat special foods. In addition to these expenses, the family has to put some money towards the funeral of the child (Brown and Warr, 2007).

\section{Spiritual needs}

At the time of the illness, family members begin to think about the meaning and purpose of human existence, life after death, and begin to recourse to higher powers. Meeting this need is also one of the coping strategies of the family. Majerníková and Jakabovičová (2008) consider basic spiritual needs as follows:

- needs of meaningful life,

- needs of meaning of self-existence,

- needs of love,

- needs of hope,

- needs of spirituality,

- needs of realization of spiritual rituals and practice,

- needs of forgiveness.

Timmins et al. (2015) wrote that clergymen should be a part of a multidisciplinary team, which take care of patient and family. Clergymen should not be just for spiritual rituals, but they should care for other family members, as support, when they need to talk about the meaning of existence and help them cope with illness and loss. Jasenková and Mikesková (2005) says, that clergyman should accompany the family during their findings for the meaning of pain, meaning of life, death and reconciliation, and also in the process of finding the truth, hope and love.

\section{Needs of surrounding}

Every family, and especially a family with a disabled or sick individual, needs to have a surrounding in which they feel good about each other. The family needs to feel that the illness of the child has not affected their lives so much that it is necessary to change the whole family functioning. Although, the WHO (cited by Marmot et al., 2011) says, that there is a category of this needs, we have not been able to find out in the literature what needs fit here. Based on the literature, we think that we can address the needs of the family and the incurable ill child to be at home because the environment of a hospital or hospice does not give the family a sense of well-being and normal functioning. In addition, hospitalization divides the family by leaving one parent with the child in the hospital while the rest of the family stays at home. This need also relates to the need for privacy that occurs with some families shortly after the diagnosis is announced.

\section{Research}

Families with an incurable ill child generally pay less attention. Emphasis is placed on childcare not only on the part of experts but also on the part of the family itself. Each member of the family individually copes with the stressful situation, going through various problems and difficulties directly or indirectly related to the child's illness. Family members also have their own needs that are often unfulfilled, and although family members themselves may not be aware, failure to meet their needs may lead to later problems that may even lead to the break-up of the family.

We assume that family needs changes at different stages of illness and therefore we have just focused on identifying these needs.

The primary objective was to identify the needs of families with incurable ill individuals and to find out if the needs of the family vary and change at different stages of the illness as described by Kübler-Ross (1993).

As a basic method of research, we chose qualitative research conducted through interviews with workers who are in contact with families with an incurable ill child, and through them we tried to understand more deeply how they perceive the needs of these families within their profession. 
The participants in our research were workers, who works with families with an incurable ill child and contributing to fulfil their needs. Seven people (4 women and 3 men) were involved in the research. The length of their practice ranged from 1.5 years to 43 years, while the 43 -year-old priest did not work intensively in the field, it is still one of the parts of his spiritual service in various settings.

To obtain the data, we decided to use the semi-structured interview method. As a template of questions, we used the stages reported by Kübler-Ross $(1969,1993)$. While in the first publication in 1969 she states the stages of shock, denial, sadness and anger, balance and reorganization (cited by Harčaríková, 2014), in her 1993 publications she states the stages of denial and isolation, anger, negotiation, depression and acceptance (Kübler-Ross, 1993). Therefore, we have decided to build up the stages that are a combination of both:

1. shock,

2. denial and negation,

3. anger, feeling of injustice and curse,

4. depression and sadness,

5. reconciliation and acceptance.

Approximately the same questions were asked to each participant. The supplementary questions were not provisionally set, but if respondents' notice showed something interesting or something that would allow us to better inspects the situation described, the respondent was asked about it. Based on the research questions, we have identified 3 headings that were tailored to the questions put by the respondent:

1. Work and experience in the field.

2. The greatest perceived need for a family.

3. The needs of the family in each stage of the child's illness.

The participants' responses showed that the needs of the family with an incurable ill child at the various stages of the death-related reconciliation described by Kübler-Ross (1993) are different. Respondents described the needs of the family from their point of view, some attempting to describe the needs as objectively as possible and some describe the needs of the family solely from the point of view of their profession.

At the stage of shock or shortly after the communication of diagnosis, psychological needs occurr. The most significant was the need for information. We measured that this need is mainly related to the phase of shock, when the family find out the diagnosis and the family is not focusing on the information that is being given to them and therefore has a greater need to ask. This need may also be related to the transition to the stage of denial, when the family needs to constantly verify the information. In the stage of denial and negation, there were significant psychological needs, especially the need to decide on treatment in the search for alternative medicine. As we have already mentioned, this need is primarily related to hope. The family denies the illness and still has the hope of reversing the adverse diagnosis. In the stage of anger, injustice, and cripples, we did not find any great need, but we noticed that the needs that families considered important in this stage are primarily psychological and psychosocial and are related to emotion ventilation, psychosocial support and assurance that no one is responsible, that the child is dying. The stage of sadness, despair and depression was characterized by psychosocial needs, particularly those of the family. The family had an increased need to be together, need of support from family members was important, but also overall psychosocial support, whether from a palliative care team or close relatives. Also, during this stage, families needed time and space to ventilate their emotions and gather strength. This was characteristic of the families that remained in the ward. At the last stage, the stage of acceptance and reconciliation, the biggest need was for being together as a family, to spend the last moments of life with the child, but also the need for the minimization of suffering.

Research has shown us that the needs of a family of an incurable ill child are changing in the various stages (Kubler-Ross, 1993). In some cases, the needs are clearly linked to the stages of reconciliation with death, but in some cases, they stem from the progress of the child's illness and naturally occur with the new situations and tasks that the family has to deal with at the time. However, the needs in the various stages and needs related to the progression of the illness cannot be separated because the stages are to a certain extent dependent on the progression of the illness and these stages occur in parallel with the illness of the child. 
Of the needs that were reported during the individual stages, no particular need emerged as a need that would persist throughout the illness, but at each stage there was at least one respondent's psychological need for the child to minimalize suffering and to receive the best care and effort to do for a child what is in the power of the family that we could summarize in one need - to keep the child from suffering. Some participants have identified the needs that they think will persist throughout the illness. Here was mentioned the need for psychosocial support, the need for support and contact with the team of palliative care and financial need. The reason why no specific need has been stated as persisting may be that participants always have the strongest need at a given stage and do not perceive all needs.

Participant's responds at individual stages can be marked as valid in relation to the last question that examined their validity.

\section{Conclusion}

Our research has shown that the needs of families are changing in the various stages of reconciliation with the death and stages of child illness. Each stage is different, each family is specific. On the basis of the data we have obtained, we have decided to formulate some recommendations: In the care, perceive the family as a whole, because the illness does not only concern the ill child, but the whole family as well. Throughout the illness, focus on psychosocial support and family support, also focus on providing quality care for the ill child. Provide to the family time and space after the reporting of the diagnosis and adapt it to their current mental state. Sufficiently inform the family about diagnosis, prognosis and treatment. Also provide information about medication, their desirable and unwanted effects throughout the illness so that parents feel they are participating in the treatment, have confidence in the health care system and thus avoid alternative medicine. In a stage of anger and feelings of injustice and curses, allow the family to express their emotions, communicate with their family about their fears, rationalize their conclusions, and make sure that no one is responsible for the child's death. In the terminal stage of illness allow the family to be together. During work with family, focus on the survival of individual members, reflect their state and offer them the possibility to help. Invite parents to communicate with the ill child and sibling, as well as open communication between the parents themselves. Engage siblings in the context of illness and educate parents about the importance of this activity. In the work with expressing the emotions of siblings and parents, use the possibility of expressive therapies, or recommend partner therapy to parents. In the field of professions that work with the family we would like to recommend above all the provision of quality supervision, which should be primarily a matter of the facilities in which employees work.

\section{References}

Brown, E. (2009). Supporting the Siblings of Life-Limited Children. https://doi.org/10.12968/bjsn.2009.4.6.43225

Brown, E., Warr, B. (2007). Supporting the Child and the Family in Pediatric Palliatice Care. London: Jessica Kingsley Publishers.

Eiser, C., Upton, P. (2006). Costs of caring for a child with cancer: a questionnaire survey. https:// 10.1111/j.13652214.2006.00710.x

Hallstrom, I., Elander, G. (2007). Families' needs when a child is long-term ill. https://10.1111/j.1440-172X.2007.00625.x

Harčaríková, T. (2014). Pedagogika telesne postihnutých, chorých a zdravotne oslabených v kontexte edukácie. Ostrava: Ostravská univerzita v Ostravě, Pedagogická fakulta.

Jasenková, M., Mikesková, M. (2005). Pomáhat’ žit', zomierat', radovat’ sa a smútit'. Bratislava: CICERO.

Kohoutek, R. (2009). Potřeby jako motivy chování a prožívání. Retrieved from http://rudolfkohoutek.blog.cz/0912/potrebyjako-motivy-chovania-prozivani

Kübler-Ross, E. (1993). About death and dying. Praha: Arica

Lane, C., Mason, J. (2014). Meeting the Needs of Siblings of Children with Life-Limiting Illness. https://10.7748/ncyp2014.04.26.3.16.e349

Lavee, Y., Mey-Dan, M. (2003). Patterns of Change in Marital Relationship Among Parents of Children with Cancer. https://10.1093/hsw/28.4.255

Machado, S. a kol. (2010). Impact of Childhood Cancer on Parents' Relationship. https://10.1111/j.1547-5069.2010.01360.x. Majerníková, L., Jakabovičová, A. (2008). Saturácia spirituálnych potrieb u onkologického pacienta. Onkologická péče, 12 , 22-24.

Marmot, M., et.al. (2011). The psychological and social needs of patients. Retrieved January, 3, 2019, from http://www.ahsw.org.uk/userfiles/Other_Resources/Health_Social_Care_Wellbeing/psychologicalsocialneedsofpatients_tc m41-202964_copy.pdf

Maslow, A. (1943). Theory of Human Motivation. Psychological review, 50, 370-396. 
Matejček, Z. (2014). Základné psychické problémy člověka. Retrieved January, 3, 2019, from http://www.nahradnirodina.cz/files/File/Skoleni_metodik_rijen_2014/Prezentace/Zakladne_psychicke_potreby_loveka.pdf Ondrinová, I., Cínová, J. (2013). Umieranie diet’at’a v kontexte špecifík vývinových období a význam podpory rodiny.Retrieved from http://zdravi.euro.cz/clanek/postgradualni-medicina/umieranie-dietata-v-kontexte-specifikvyvinovych-obdobi-a-vyznam-podpory-rodiny-468592

Timmins, F., Naughton, M., Plakas, S. (2015). Supporting patients' and families' religious and spiritual needs in ICU. British Asociation of Critical Care Nurses, 20, 115-117.

Yoshida, S. et.al. (2014). A Comprehensive Study of Distressing Experiences and Support Needs of Parents of Children with Intractable Cancer. Japanesse Journal of Clinical Oncology, 44, 1181-1188. 